\title{
Dietzia alimentaria sp. nov., isolated from a traditional Korean food
}

\author{
Jandi Kim, ${ }^{1}$ Seong Woon Roh, ${ }^{1}$ Jung-Hye Choi, ${ }^{1}$ Mi-Ja Jung, ${ }^{1}$ \\ Young-Do Nam, ${ }^{1}$ Min-Soo Kim, ${ }^{1}$ Eun-Jin Park, ${ }^{1}$ Kee-Sun Shin ${ }^{2}$ \\ and Jin-Woo Bae ${ }^{1}$
}

Correspondence

Jin-Woo Bae

baejw@khu.ac.kr

\author{
${ }^{1}$ Department of Life and Nanopharmaceutical Sciences and Department of Biology, Kyung Hee \\ University, Seoul 130-701, Republic of Korea \\ ${ }^{2}$ Korea Research Institute of Bioscience and Biotechnology (KRIBB), Daejeon 305-806, Republic \\ of Korea
}

The genus Dietzia was proposed by Rainey et al. (1995) to accommodate Rhodococcus maris (Nesterenko et al., 1982) and includes eight species at the time of writing. Members of the genus have been isolated from a number of different environments, including skin, hospitals, plant tissue, soil and seawater (Duckworth et al., 1998; Rainey et al., 1995; Yumoto et al., 2002). Dietzia maris strains have been isolated from soil, seawater and hospital environments (Colquhoun et al., 1998; Nesterenko et al., 1982; Rainey et al., 1995; Takami et al., 1997), Dietzia natronolimnaea from an alkaline East African soda lake (Duckworth et al., 1998), Dietzia psychralcaliphila from a drain pool of a fishegg-processing plant (Yumoto et al., 2002), Dietzia cinnamea from a perianal swab of a patient after bonemarrow transplantation (Yassin et al., 2006), Dietzia kunjamensis from a cold desert soil (Mayilraj et al., 2006), Dietzia papillomatosis from the skin of an immunocompetent patient with confluent papillomatosis (Jones et al., 2008) and Dietzia schimae and Dietzia cercidiphylli from surface-sterilized plant tissues (Li et al., 2008).

Strain $72^{\mathrm{T}}$ was isolated from a traditional salt-fermented seafood made by fermenting fresh clams mixed with rock

The GenBank/EMBL/DDBJ accession number for the 16S rRNA gene sequence of strain $72^{\top}$ is GQ368824.

Two supplementary figures are available with the online version of this paper. salt for 2 weeks (Suh \& Yoon, 1987). The purified strain was cultured on tryptic soy agar (TSA; BBL) and marine agar (MA; BBL) at $30{ }^{\circ} \mathrm{C}$ for 5 days. Cell morphology was inspected by light microscopy (ECLIPSE 50i; Nikon) and transmission electron microscopy (JEM-1010; JEOL). Growth at $4,15,25,30,37$ and $45{ }^{\circ} \mathrm{C}$, with $0-10 \% \mathrm{NaCl}$ (at intervals of $1 \%$ ) and 15 and $20 \% \mathrm{NaCl}$ and at $\mathrm{pH} 2.0$ 13.0 (at intervals of $1 \mathrm{pH}$ unit) was tested in marine broth (BBL). The Gram reaction was performed using the nonstaining method described by Buck (1982). Hydrolysis of starch, gelatin and Tweens $20,40,60$ and 80 (1\% on MA) was performed as described by Smibert \& Krieg (1994). $\mathrm{H}_{2} \mathrm{~S}$ production, citrate utilization, the Voges-Proskauer reaction and the methyl red test were performed according to described methods (Goodfellow, 1986). Motility was examined using the method of Tittsler \& Sandholzer (1936) in semi-solid agar (motility test medium; BBL). Enzyme activity and utilization of sole carbon sources were determined using the API ZYM, API 20NE and API $50 \mathrm{CH}$ kits (bioMérieux) according to the manufacturer's instructions. Cells of strain $72^{\mathrm{T}}$ were Gram-reaction-positive, nonmotile rods, $1-1.5 \mu \mathrm{m}$ in diameter. They were positive for catalase, but negative for oxidase. The isolate was positive for hydrolysis of Tweens 20, 40, 60 and 80. Growth occurred at $\mathrm{pH} 7-10$ (optimum $\mathrm{pH} 7.0$ ), with $0-10 \%$ $\mathrm{NaCl}$ (optimum $2 \% \mathrm{NaCl}$ ) and at $15-37{ }^{\circ} \mathrm{C}$ (optimum $30{ }^{\circ} \mathrm{C}$ ). The species description gives further phenotypic 
details and Table 1 provides a phenotypic comparison of strain $72^{\mathrm{T}}$ with members of the genus Dietzia.

Reference strains D. maris JCM $6166^{\mathrm{T}}$, D. kunjamensis JCM $13325^{\mathrm{T}}, D$. cinnamea JCM $13663^{\mathrm{T}}$ and $D$. natronolimnaea JCM $11417^{\mathrm{T}}$ were obtained from the Japan Collection of Microorganisms and reference strains D. schimae DSM $45139^{\mathrm{T}}$, D. cercidiphylli DSM $45140^{\mathrm{T}}$ and D. psychralcaliphila DSM $44820^{\mathrm{T}}$ were obtained from the Deutsche Sammlung von Mikroorganismen und Zellkulturen. The 16S rRNA gene was amplified with PCR Pre-Mix (Solgent) using the colony PCR method (Baker et al., 2003). The resulting PCR products were purified using a PCR purification kit (Qiagen) and sequenced using a BigDye Terminator cycle sequencing ready reaction kit (Applied Biosystems) as described previously (Roh et al., 2008). The almost-full-length 16S rRNA gene sequence was assembled using SeqMan software (DNASTAR). 16S rRNA gene sequences from strain $72^{\mathrm{T}}$ and related taxa obtained from the NCBI database were aligned using CLUSTAL $\mathrm{x}$ version 1.8 (Thompson et al., 1997), trimmed and converted to MEGA format for phylogenetic analysis. Phylogenetic consensus trees were constructed using the neighbour-joining (Saitou \& Nei, 1987) and maximum-parsimony (Kluge \& Farris, 1969) methods. Phylogenetic relationships between the isolate and representative members of the genus Dietzia were determined using MEGA4 (Tamura et al., 2007) and the topologies of the resultant trees were estimated using bootstrap analysis (Felsenstein, 1985) based on 1000 replicates. The phylogenetic relationships between strain $72^{\mathrm{T}}$ and its relatives in the genus Dietzia are shown in Fig. 1. Strain $72^{\mathrm{T}}$ exhibited 98.6, 98.5, 98.4, 98.1, 98.0, 97.9 and $97.5 \% 16 \mathrm{~S}$ rRNA gene sequence similarity with $D$. maris DSM $43672^{\mathrm{T}}$, D. schimae YIM $65001^{\mathrm{T}}, D$. psychralcaliphila ILA- ${ }^{\mathrm{T}}$, D. kunjamensis $\mathrm{K} 30-10^{\mathrm{T}}$, D. cercidiphylli YIM $65002^{\mathrm{T}}$, D. natronolimnaea CBS $107.95^{\mathrm{T}}$ and D. cinnamea IMMIB RIV-339 ${ }^{\mathrm{T}}$, respectively.

DNA-DNA hybridization was performed in quintuplicate using microarrays according to Bae et al. (2005). Strain $72^{\mathrm{T}}$ showed low levels of DNA-DNA relatedness with $D$. maris JCM $6166^{\mathrm{T}}(17.8 \pm 2.9 \%)$, D. schimae DSM $45139^{\mathrm{T}}(18.5$ $\pm 1.1 \%)$, D. psychralcaliphila DSM $44820^{\mathrm{T}}(21.3 \pm 1.7 \%)$, D. kunjamensis JCM $13325^{\mathrm{T}}(17.0 \pm 2.6 \%)$, D. cercidiphylli DSM $45140^{\mathrm{T}}(26.7 \pm 8.3 \%)$, D. natronolimnaea JCM $11417^{\mathrm{T}}$ $(9.6 \pm 2.7 \%)$ and $D$. cinnamea JCM $13663^{\mathrm{T}}(21.9 \pm 5.8 \%)$.

Analysis of the cellular fatty acid composition of strain $72^{\mathrm{T}}$ was performed according to the Sherlock Microbial Identification System (MIDI). Fatty acids were analysed by gas chromatography (Hewlett Packard 6890) with cells grown on TSA at $30{ }^{\circ} \mathrm{C}$ for 3 days. The fatty acids were $\mathrm{C}_{16: 0}\left(15.5 \%\right.$ ), summed feature 3 (comprising $\mathrm{C}_{16: 1} \omega 6 c$ and/or $\left.\mathrm{C}_{16: 1} \omega 7 c ; 15.1 \%\right), 10$-methyl $\mathrm{C}_{18: 0}(14.6 \%), \mathrm{C}_{17: 0}$ $(10.8 \%), \quad \mathrm{C}_{19: 0} \quad(9.1 \%), \mathrm{C}_{18: 1} \omega 9 \mathrm{c} \quad(7.4 \%), \mathrm{C}_{17: 1} \omega 7 c$ $(4.9 \%)$ and $\mathrm{C}_{20: 1} \omega 9 c(4.5 \%)$; other fatty acids were present in small amounts $(<4 \%)$. The amino-acid composition of the cell-wall hydrolysate was determined using one-dimensional TLC on cellulose sheets (Bousfield et al., 1985). The major polar lipids were extracted using the method of Xin et al. (2000), separated by twodimensional TLC on a Merck silica gel $60 \mathrm{~F}_{254}$ glassbacked plate with chloroform/methanol/water $(65: 25: 4$, by vol.) in the first dimension and chloroform/acetic acid/ methanol/water $(80: 15: 12: 4$, by vol.) in the second dimension and detected by spraying the plate with specific reagents, as described by Tindall (1990). The designations of all spots were according to Kämpfer et al. (2010). The polar lipids present were diphosphatidylglycerol, phosphatidylglycerol, phosphatidylinositol, phosphatidylinositol mannoside, an unknown phospholipid, six unknown glycolipids, an unknown aminolipid and an unknown lipid (Supplementary Fig. S1, available in IJSEM Online). Mycolic acids were determined using one-dimensional TLC on cellulose sheets (Minnikin et al., 1975; Supplementary Fig. S2). Cell-wall sugars were separated by onedimensional TLC on a Merck silica gel $60 \mathrm{~F}_{254}$ glass-backed plate with $n$-butanol/water/pyridine/toluene (10:6:6:1, by vol.) using the method of Lechevalier (1968). The cellwall sugars were arabinose and galactose. Quinone extraction and identification was performed according to the method of Komagata \& Suzuki (1987); the major isoprenoid menaquinone of the isolate was MK- $8\left(\mathrm{H}_{2}\right)$.

The $\mathrm{G}+\mathrm{C}$ content of strain $72^{\mathrm{T}}$ and the reference strains $D$. psychralcaliphila ILA- $1^{\mathrm{T}}$ and D. kunjamensis $\mathrm{K} 30-10^{\mathrm{T}}$ was determined using SYBR Green I and real-time PCR (Gonzalez \& Saiz-Jimenez, 2002). Genomic DNA from Bacteroides finegoldii DSM $17565^{\mathrm{T}}$ and Escherichia coli K-12 (obtained from KCTC) was used for calibration. The DNA $\mathrm{G}+\mathrm{C}$ content of the isolate was $64.7 \mathrm{~mol} \%$. The lowest genomic DNA G $+\mathrm{C}$ content observed thus far for the genus Dietzia is $66 \mathrm{~mol} \%$ (Duckworth et al., 1998) and the highest is $73 \mathrm{~mol} \%$ (Rainey et al., 1995). The DNA G + C content of strain $72^{\mathrm{T}}$ is slightly lower than those reported for members of the genus Dietzia with validly published names.

On the basis of genotypic, chemotaxonomic and phenotypic data, strain $72^{\mathrm{T}}$ represents a novel species of the genus Dietzia, for which the name Dietzia alimentaria sp. nov. is proposed.

\section{Description of Dietzia alimentaria sp. nov.}

Dietzia alimentaria (a.li.men.ta' ri.a. L. fem. adj. alimentaria pertaining to food).

Colonies are opaque, smooth, circular, convex, entire and shiny in appearance, with a coral-red pigment and approximately $1-2 \mathrm{~mm}$ in diameter after 5 days on marine agar at $30{ }^{\circ} \mathrm{C}$. Cells are rods $(1-1.5 \mu \mathrm{m}$ wide), Gramreaction-positive, non-motile, catalase-positive and oxidasenegative. Growth occurs at $\mathrm{pH} 7-10$ (optimum $\mathrm{pH}$ 7.0), with $0-10 \% \mathrm{NaCl}$ (optimum $2 \% \mathrm{NaCl}$ ) and at $15-37{ }^{\circ} \mathrm{C}$ (optimum $30{ }^{\circ} \mathrm{C}$ ). No growth at $45{ }^{\circ} \mathrm{C}$. Positive for hydrolysis of Tweens 20, 40, 60 and 80 but negative for hydrolysis of casein and starch. With API ZYM, positive for esterase (C4), alkaline phosphatase, esterase lipase and naphthol-AS-BI-phosphohydrolase and negative for lipase 
Table 1. Differential characteristics of strain $72^{\top}$ and type strains of species of the genus Dietzia

Strains: 1, Dietzia alimentaria sp. nov. $72^{\mathrm{T}} ; 2$, D. maris DSM $43672^{\mathrm{T}} ; 3$, D. schimae YIM $65001^{\mathrm{T}}$; 4, D. psychralcaliphila ILA-1 ${ }^{\mathrm{T}}$; 5, D. kunjamensis K30-10 ${ }^{\mathrm{T}} ; 6$, D. cercidiphylli YIM $65002^{\mathrm{T}} ; 7$, D. natronolimnaea CBS $107.95^{\mathrm{T}} ; 8$, D. cinnamea IMMIB RIV-399 . Data were obtained in this study. + , Positive; w, weakly positive; - , negative.

\begin{tabular}{|c|c|c|c|c|c|c|c|c|}
\hline Characteristic & 1 & 2 & 3 & 4 & 5 & 6 & 7 & 8 \\
\hline Colony colour ${ }^{\star}$ & $\mathrm{CR}$ & DO & DP & $\mathrm{CR}$ & $\mathrm{R}$ & RO & SP & Y \\
\hline Growth temperature $\left({ }^{\circ} \mathrm{C}\right)$ & $15-37$ & $10-45$ & $10-45$ & $10-37$ & $10-37$ & $10-37$ & $10-37$ & $22-45$ \\
\hline \multicolumn{9}{|l|}{ Utilization of (API $50 \mathrm{CH})$ : } \\
\hline Glycerol & - & $\mathrm{w}$ & - & + & - & - & + & - \\
\hline Erythritol & - & - & - & - & - & - & + & $\mathrm{w}$ \\
\hline D-Arabinose & - & + & - & + & - & + & + & - \\
\hline L-Arabinose & - & $\mathrm{W}$ & - & + & - & - & - & - \\
\hline D-Ribose & - & + & $\mathrm{w}$ & - & $\mathrm{w}$ & - & + & $\mathrm{w}$ \\
\hline D-Xylose & - & + & - & - & + & $\mathrm{W}$ & - & + \\
\hline L-Xylose & - & + & - & - & - & - & - & - \\
\hline D-Adonitol & - & + & - & - & - & + & $\mathrm{w}$ & - \\
\hline Methyl $\beta$-D-xylopyranoside & + & + & - & - & - & + & $\mathrm{w}$ & - \\
\hline D-Galactose & - & + & - & - & $\mathrm{W}$ & - & + & - \\
\hline D-Glucose & + & + & - & + & $\mathrm{W}$ & - & - & + \\
\hline D-Fructose & $\mathrm{W}$ & + & + & + & + & + & - & + \\
\hline D-Mannose & + & + & + & $\mathrm{w}$ & $\mathrm{w}$ & - & + & - \\
\hline L-Sorbose & + & + & $\mathrm{w}$ & + & - & - & + & - \\
\hline L-Rhamnose & + & + & + & + & + & - & + & - \\
\hline Dulcitol & + & + & - & + & - & $\mathrm{w}$ & + & - \\
\hline Inositol & $\mathrm{w}$ & + & + & + & $\mathrm{w}$ & - & - & - \\
\hline D-Mannitol & $\mathrm{w}$ & + & + & + & - & - & - & - \\
\hline D-Sorbitol & $\mathrm{w}$ & + & - & + & - & - & - & - \\
\hline Methyl $\alpha$-D-mannopyranoside & - & + & - & + & - & - & + & - \\
\hline Methyl $\alpha$-D-glucopyranoside & - & + & + & - & - & - & + & + \\
\hline$N$-Acetylglucosamine & + & + & $\mathrm{W}$ & $\mathrm{w}$ & - & + & + & $\mathrm{w}$ \\
\hline Amygdalin & - & $\mathrm{w}$ & $\mathrm{w}$ & + & - & - & $\mathrm{W}$ & - \\
\hline Arbutin & + & + & - & $\mathrm{w}$ & + & - & - & - \\
\hline Aesculin & + & + & + & + & + & + & - & - \\
\hline Salicin & + & $\mathrm{W}$ & $\mathrm{W}$ & - & - & - & - & - \\
\hline Cellobiose & - & + & + & $\mathrm{w}$ & $\mathrm{w}$ & + & - & - \\
\hline Maltose & + & $\mathrm{w}$ & + & + & $\mathrm{w}$ & - & - & - \\
\hline Lactose & + & $\mathrm{w}$ & + & - & + & - & - & - \\
\hline Melibiose & - & + & - & - & + & + & - & + \\
\hline Sucrose & + & + & + & + & + & + & - & + \\
\hline Trehalose & + & + & + & - & - & + & - & - \\
\hline Inulin & + & + & + & + & + & + & - & + \\
\hline Melezitose & - & + & + & + & + & + & - & + \\
\hline Raffinose & - & + & - & - & $\mathrm{w}$ & + & - & - \\
\hline Starch & + & + & + & + & + & + & - & - \\
\hline Glycogen & + & + & + & + & + & + & - & + \\
\hline Xylitol & - & $\mathrm{w}$ & + & - & + & + & - & - \\
\hline Gentiobiose & - & $\mathrm{w}$ & + & - & + & + & - & - \\
\hline Turanose & - & + & - & + & + & - & - & - \\
\hline D-Lyxose & - & - & - & - & + & - & + & - \\
\hline D-Tagatose & - & - & - & + & + & - & - & - \\
\hline D-Fucose & - & - & - & + & $\mathrm{w}$ & - & - & - \\
\hline L-Fucose & - & - & - & + & + & - & - & - \\
\hline D-Arabitol & $\mathrm{w}$ & - & - & $\mathrm{w}$ & + & - & - & - \\
\hline L-Arabitol & - & - & - & + & + & - & - & - \\
\hline Potassium gluconate & - & - & - & - & + & - & - & - \\
\hline Potassium 2-ketogluconate & - & - & - & - & + & - & - & - \\
\hline Potassium 5-ketogluconate & $\mathrm{w}$ & $\mathrm{w}$ & - & + & + & - & - & - \\
\hline
\end{tabular}

${ }^{\star} \mathrm{CR}$, Coral red; DO, deep orange; DP, deep pink; R, red; RO, reddish orange; sP, soft pink; Y, yellow. 


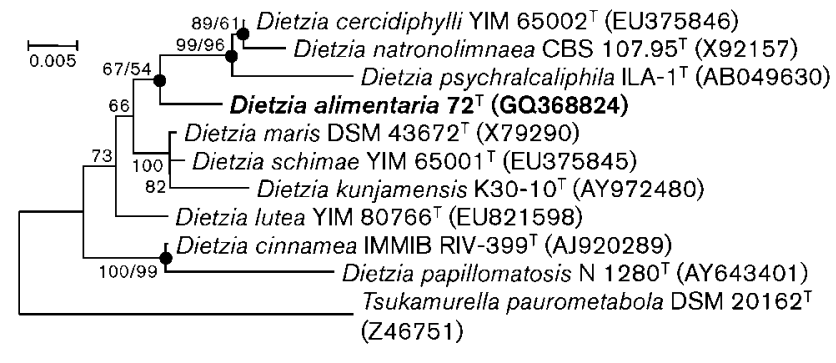

Fig. 1. 16S rRNA gene sequence-based phylogenetic consensus tree reconstructed using the neighbour-joining algorithm, showing the position of strain $72^{\top}$ in the genus Dietzia. Filled circles indicate nodes that were also recovered using the maximum-parsimony algorithm. Bootstrap values ( $>50 \%$ ) based on 1000 replications are shown at branch nodes (neighbour joining/maximum parsimony). Bar, 0.005 accumulated changes per nucleotide.

(C14), leucine arylamidase, valine arylamidase, trypsin, $\alpha$ chymotrypsin, $\alpha$-galactosidase, $\beta$-glucuronidase, $\beta$ - and $\alpha$ glucosidase, $N$-acetyl- $\beta$-glucosaminidase, $\alpha$-mannosidase and $\alpha$-fucosidase; acid phosphatase reaction is weak. With API 20NE, positive for reduction of nitrates to nitrogen, fermentation of D-glucose and assimilation of adipic acid, malic acid and trisodium citrate and weakly positive for assimilation of D-mannose; negative for production of indole, assimilation of potassium gluconate, urease and $\beta$ galactosidase activity (4-nitrophenyl $\beta$-D-galactopyranoside hydrolysis) and assimilation of D-glucose, L-arabinose, Dmannitol, $N$-acetylglucosamine, maltose, capric acid and phenylacetic acid. With API $50 \mathrm{CH}$, assimilates methyl $\beta$-Dxylopyranoside, D-glucose, D-mannose, L-sorbose, L-rhamnose, dulcitol, $N$-acetylglucosamine, arbutin, aesculin, salicin, maltose, lactose, sucrose, trehalose, inulin, starch and glycogen, assimilates D-fructose, inositol, D-mannitol, Dsorbitol, D-arabitol and potassium 5-ketogluconate weakly, but does not assimilate glycerol, erythritol, D- or L-arabinose, D-ribose, D- or L-xylose, D-adonitol, D-galactose, methyl $\alpha$-Dmannopyranoside, methyl $\alpha$-D-glucopyranoside, amygdalin, cellobiose, melibiose, melezitose, raffinose, xylitol, gentiobiose, turanose, D-lyxose, D-tagatose, D- or L-fucose, L-arabitol, potassium gluconate or potassium 2-ketogluconate. Wholecell hydrolysates show the main cell-wall components to be meso-diaminopimelic acid, arabinose and galactose. The major fatty acids $(>5 \%)$ are $\mathrm{C}_{16: 0}$, summed feature $3\left(\mathrm{C}_{16: 1} \omega 6 c\right.$ and/or $\left.\mathrm{C}_{16: 1} \omega 7 c\right)$, 10-methyl $\mathrm{C}_{18: 0}, \mathrm{C}_{17: 0}, \mathrm{C}_{19: 0}$ and $\mathrm{C}_{18: 1} \omega 9 c$. Mycolic acids are present. The polar lipids are diphosphatidylglycerol, phosphatidylglycerol, phosphatidylinositol, phosphatidylinositol mannoside, an unknown phospholipid, six unknown glycolipids, an unknown aminolipid and an unknown lipid. The major isoprenoid menaquinone is MK- $8\left(\mathrm{H}_{2}\right)$. The DNA $\mathrm{G}+\mathrm{C}$ content of the type strain is $64.7 \mathrm{~mol} \%$.

The type strain, $72^{\mathrm{T}}\left(=\mathrm{JCM} 16360^{\mathrm{T}}=\right.$ KACC $21126^{\mathrm{T}}$ ), was isolated from a traditional salt-fermented seafood made of clam jeotgal from Sokcho, Korea.

\section{Acknowledgements}

We thank Dr J. P. Euzéby (Ecole Nationale Vétérinaire, France) for etymological advice. This work was supported by TDPAF (Technology Development Program for Agriculture and Forestry).

\section{References}

Bae, J. W., Rhee, S. K., Park, J. R., Chung, W. H., Nam, Y. D., Lee, I., Kim, H. \& Park, Y. H. (2005). Development and evaluation of genomeprobing microarrays for monitoring lactic acid bacteria. Appl Environ Microbiol 71, 8825-8835.

Baker, G. C., Smith, J. J. \& Cowan, D. A. (2003). Review and re-analysis of domain-specific 16S primers. J Microbiol Methods 55, 541-555.

Bousfield, I. J., Keddie, R. M., Dando, T. R. \& Shaw, S. (1985). Simple rapid methods of cell wall analysis as an aid in the identification of aerobic coryneform bacteria. In Chemical Methods in Bacterial Systematics, pp. 221-236. Edited by M. Goodfellow \& D. E. Minnikin. London: Academic Press.

Buck, J. D. (1982). Nonstaining ( $\mathrm{KOH})$ method for determination of gram reactions of marine bacteria. Appl Environ Microbiol 44, 992-993.

Colquhoun, J. A., Mexson, J., Goodfellow, M., Ward, A. C., Horikoshi, K. \& Bull, A. T. (1998). Novel rhodococci and other mycolate actinomycetes from the deep sea. Antonie van Leeuwenhoek 74, 27-40.

Duckworth, A. W., Grant, S., Grant, W. D., Jones, B. E. \& Meijer, D. (1998). Dietzia natronolimnaios sp. nov., a new member of the genus Dietzia isolated from an east African soda lake. Extremophiles 2, 359-366.

Felsenstein, J. (1985). Confidence limits on phylogenies: an approach using the bootstrap. Evolution 39, 783-791.

Gonzalez, J. M. \& Saiz-Jimenez, C. (2002). A fluorimetric method for the estimation of $\mathrm{G}+\mathrm{C}$ mol\% content in microorganisms by thermal denaturation temperature. Environ Microbiol 4, 770-773.

Goodfellow, M. (1986). Genus Rhodococcus Zopf 1891, $28^{\mathrm{AL}}$. In Bergey's Manual of Systematic Bacteriology, vol. 2, pp. 1472-1481. Edited by P. H. A. Sneath, N. S. Mair, M. E. Sharpe \& J. G. Holt. Baltimore: Williams \& Wilkins.

Jones, A. L., Koerner, R. J., Natarajan, S., Perry, J. D. \& Goodfellow, M. (2008). Dietzia papillomatosis sp. nov., a novel actinomycete isolated from the skin of an immunocompetent patient with confluent and reticulated papillomatosis. Int J Syst Evol Microbiol 58, 68-72.

Kämpfer, P., Langer, S., Martin, E., Jäckel, U. \& Busse, H. J. (2010). Dietzia aerolata sp. nov., isolated from the air of a duck barn, and emended description of the genus Dietzia Rainey et al. 1995. Int J Syst Evol Microbiol 60, 393-396.

Kluge, A. G. \& Farris, F. S. (1969). Quantitative phyletics and the evolution of anurans. Syst Zool 18, 1-32.

Komagata, K. \& Suzuki, K. (1987). Lipid and cell-wall analysis in bacterial systematics. Methods Microbiol 19, 161-207.

Lechevalier, M. P. (1968). Identification of aerobic actinomycetes of clinical importance. J Lab Clin Med 71, 934-944.

Li, J., Zhao, G.-Z., Zhang, Y.-Q., Klenk, H.-P., Pukall, R., Qin, S., Xu, L.-H. \& Li, W.-J. (2008). Dietzia schimae sp. nov. and Dietzia cercidiphylli sp. nov., from surface-sterilized plant tissues. Int J Syst Evol Microbiol 58, 2549-2554.

Mayilraj, S., Suresh, K., Kroppenstedt, R. M. \& Saini, H. S. (2006). Dietzia kunjamensis sp. nov., isolated from the Indian Himalayas. Int J Syst Evol Microbiol 56, 1667-1671.

Minnikin, D. E., Alshamaony, L. \& Goodfellow, M. (1975). Differentiation of Mycobacterium, Nocardia, and related taxa by thin-layer chromatographic analysis of whole-organism methanolysates. J Gen Microbiol 88, 200-204. 
Nesterenko, O. A., Nogina, T. M., Kasumova, S. A., Kvasnikov, E. I. \& Batrakov, S. G. (1982). Rhodococcus luteus nom. nov. and Rhodococcus maris nom. nov. Int J Syst Bacteriol 32, 1-14.

Rainey, F. A., Klatte, S., Kroppenstedt, R. M. \& Stackebrandt, E. (1995). Dietzia, a new genus including Dietzia maris comb. nov., formerly Rhodococcus maris. Int J Syst Bacteriol 45, 32-36.

Roh, S. W., Sung, Y., Nam, Y. D., Chang, H. W., Kim, K. H., Yoon, J. H., Jeon, C. O., Oh, H. M. \& Bae, J. W. (2008). Arthrobacter soli sp. nov., a novel bacterium isolated from wastewater reservoir sediment. J Microbiol 46, 40-44.

Saitou, N. \& Nei, M. (1987). The neighbor-joining method: a new method for reconstructing phylogenetic trees. Mol Biol Evol 4, 406-425.

Smibert, R. M. \& Krieg, N. R. (1994). Phenotypic characterization. In Methods for General and Molecular Bacteriology, pp. 607-654. Edited by P. Gerhardt, R. G. E. Murray, W. A. Wood \& N. R. Krieg. Washington, DC: American Society for Microbiology.

Suh, H. K. \& Yoon, S. S. (1987). A study on the regional characteristics of Korean chotkal. Korean J Dietary Cult 2, 45-54.

Takami, H., Inoue, A., Fuji, F. \& Horikoshi, K. (1997). Microbial flora in the deepest sea mud of the Mariana Trench. FEMS Microbiol Lett 152, 279-285.
Tamura, K., Dudley, J., Nei, M. \& Kumar, S. (2007). MEGA4: molecular evolutionary genetics analysis (MEGA) software version 4.0. Mol Biol Evol 24, 1596-1599.

Thompson, J. D., Gibson, T. J., Plewniak, F., Jeanmougin, F. \& Higgins, D. G. (1997). The CLUSTAL_X windows interface: flexible strategies for multiple sequence alignment aided by quality analysis tools. Nucleic Acids Res 25, 4876-4882.

Tindall, B. J. (1990). Lipid composition of Halobacterium lacusprofundi. FEMS Microbiol Lett 66, 199-202.

Tittsler, R. P. \& Sandholzer, L. A. (1936). The use of semi-solid agar for the detection of bacterial motility. J Bacteriol 31, 575-580.

Xin, H., Itoh, T., Zhou, P., Suzuki, K., Kamekura, M. \& Nakase, T. (2000). Natrinema versiforme sp. nov., an extremely halophilic archaeon from Aibi salt lake, Xinjiang, China. Int J Syst Evol Microbiol 50, 1297-1303.

Yassin, A. F., Hupfer, H. \& Schaal, K. P. (2006). Dietzia cinnamea sp. nov., a novel species isolated from a perianal swab of a patient with a bone marrow transplant. Int J Syst Evol Microbiol 56, 641-645.

Yumoto, I., Nakamura, A., Iwata, H., Kojima, K., Kusumoto, K., Nodasaka, Y. \& Matsuyama, H. (2002). Dietzia psychralcaliphila sp. nov., a novel, facultatively psychrophilic alkaliphile that grows on hydrocarbons. Int J Syst Evol Microbiol 52, 85-90. 